Article

\title{
Level of Financial Performance of Selected Construction Companies in South Africa
}

\author{
Emmanuel Dele Omopariola ${ }^{1}\left(\mathbb{D}\right.$, Abimbola Windapo ${ }^{1}\left(\mathbb{D}\right.$, David John Edwards ${ }^{2,3, *(\mathbb{D})}$ and Hatem El-Gohary ${ }^{4}(\mathbb{D}$ \\ 1 Department of Construction Economics and Management, University of Cape Town, \\ Cape Town 7701, South Africa; ompemm002@myuct.ac.za or felixdelly@yahoo.com (E.D.O.); \\ abimbola.windapo@uct.ac.za (A.W.) \\ 2 School of Engineering and Built Environment, Birmingham City University, Birmingham B4 7BD, UK \\ 3 Faculty of Engineering and the Built Environment, University of Johannesburg, \\ Johannesburg 2092, South Africa \\ 4 College of Business and Economics, Qatar University, P.O. Box 2713, Al Rayyan 00974, Qatar; \\ elgohary70@yahoo.com \\ * Correspondence: drdavidedwards@aol.com
}

check for updates

Citation: Omopariola, Emmanuel Dele, Abimbola Windapo, David John Edwards, and Hatem El-Gohary. 2021. Level of Financial Performance of Selected Construction Companies in South Africa. Journal of Risk and Financial Management 14: 518. https: / /doi.org/10.3390/ jrfm14110518

Academic Editor: Ştefan Cristian Gherghina

Received: 2 September 2021

Accepted: 14 October 2021

Published: 27 October 2021

Publisher's Note: MDPI stays neutral with regard to jurisdictional claims in published maps and institutional affiliations.

Copyright: (c) 2021 by the authors. Licensee MDPI, Basel, Switzerland. This article is an open access article distributed under the terms and conditions of the Creative Commons Attribution (CC BY) license (https:// creativecommons.org/licenses/by/ $4.0 /)$.

\begin{abstract}
Purpose-There is no consensus on the indicators that assess a construction company's financial performance projects undertaken. There is also a dearth of concepts on the financial performance indicators for construction companies in South Africa and indeed, the wider continent of Africa. This paper proposes novel financial performance indicators for assessing construction organizations and tests these on selected construction companies in the South African construction industry. Design/methodology/approach-This research employed a pragmatic approach. Contractors with financial credibility and capacity of $\geq R 40$ million, annual turnover of $\geq R 20$ million, and available capital of $\geq R 40$ million were purposively selected for this study. Parameters such as total revenue, direct cost of work, total indirect cost and total income were elicited from the sample contractors to assess their financial performance. The assessment was undertaken using formulas that were formulated based on the descriptions provided under the research methodology. Further analysis was conducted using post hoc Tukey's honest significant difference (HSD). Findings-The study finds that construction companies with a strong structure, multiple areas of specialization, creative and efficient staff members, and access to funding, have a greater chance of experiencing higher: income; positive leverage; positive liquidity; and positive cash flow. Moreover, companies with specialization in civil engineering construction and project management skills experienced higher positive liquidity and profitability. Originality/value-This research is unique through its investigation and formulation of indicators for assessing the financial performance of construction companies. This research is consequently representing the first attempt to analyze financial data using the approaches prescribed and adopted.
\end{abstract}

Keywords: construction organization; company size; financial performance indicators; time frame; project management

\section{Introduction}

Financial performance indicators provide construction companies with an understanding of their financial health and attainment (Alfan and Zacharia 2013; Ilori and Omopariola 2018). Poor financial performance of construction projects and construction companies is an omnipresent global phenomenon (CIOB 2004; Ashworth 2006; Windapo et al. 2017). This has been attributed to the dwindling in the world economy and nonpursuit of financial growth by construction companies. Thus, it becomes vital for corporate organizations (construction companies) seeking to augment financial performance to prudently manage the operation and financial features of their businesses if they desire to have inimitable, valuable, non-substitutable and rare resources to retain a competitive 
advantage (Amato and Amato 2004; Papadogonas 2007; Odediran and Windapo 2016; Omopariola and Windapo 2018; Soewarno and Tjahjadi 2020). It is expected that the pursuit of financial growth and well-being will lead to the appropriate application and management of financial performance indicators. In turn, this enhances the delivery of successful quality projects that meet clients' requirements and mitigate disputes between project stakeholders (cf. Chen 2009; Chiu and Wang 2011; Halim et al. 2014; Lai et al. 2014; Omopariola and Windapo 2019). To pursue financial growth and well-being, financial performance indicators are required (Alfan and Zacharia 2013). Yet, despite its importance there is no consensus amongst previous studies on the financial performance indicators for construction organizations.

Past research has for example, considered the financial factors that determine the success and failure of organization performance (cf. Chen 2009; Chiu and Wang 2011; Alfan and Zacharia 2013; Halim et al. 2014; Lai et al. 2014; Tucker et al. 2015). Other studies linked financial performance to the project environment. For example, Moneva and Ortas (2010) evaluated the implication of the relationship between business performance and financial performance in European establishments to demonstrate to managers how appropriate management of environmental issues contributes to the firm's financial achievement. Results revealed that companies which gained higher rates of environmental performance, exhibited improved and healthier financial performance levels in the outlook. Lam and Gale (2014) explored the financial performance of structures for highway maintenance construction projects within local government. Their work (ibid) revealed that: the use of framework procurement approaches sustains substantial cost savings when applied within a public setting environment; there are significant decreases in the entire contract costs for engagement and performance monitoring; and there is no significant alteration in production costs of tender prices. In the Korean construction industry, Woo et al. (2016) assessed the communication proficiencies for green supply chain organization and the connection between green cost decrease, company competitiveness and external green alliance, from the suppliers' perception. It was found (ibid) that suppliers with greater informationsharing skills attained competitive advantage, enhanced environmental cooperation, and contributed to green cost-saving.

Research has also investigated the relationships between strategic management and organization financial performance (cf. Maes et al. 2005; Moneva et al. 2007; Oyewobi et al. 2015). Maes et al. (2005) developed a structural model to examine the direct and indirect effects of owner-manager and firm features and selected management strategy on the financial performance of a sample of 218 small Belgian construction companies. Analysis results (ibid) found that the owner-manager and firm features (such as company size, firm age, education, knowledge of cost accounting) have a significant indirect impact on financial performance. Moneva et al. (2007) investigated whether the strategic commitment of an organization to its stakeholders in Spanish firms is positively related to its social and financial performance. The study (ibid) reported that the outcomes did not show a high level of investor approach, publication and quality of sustainability reports, and no significant relationship between variables and financial performance in the companies. In South Africa, Oyewobi et al. (2015) investigated the type of competitive strategies used by construction companies in attaining their strategic objectives. The study (ibid) reported that generic competitive strategies are related to non-financial performance and that differentiation and cost-leadership strategies are effective in assisting construction companies to realize their financial performance goals. Premised upon these previous studies, it is apparent that: there is no clear consensus on the indicators for assessing financial performance; and there is a dearth of concepts that define financial performance indicators. Therefore, the question to be answered in this study is 'what indicators can be adopted for assessing the financial performance of construction organizations towards determining the level of their financial health?' 


\section{The Concept of Financial Performance}

As a phenomenon, financial performance lack of coalescence and this has raised concerns within both academia and practice (cf. Venkatraman and Ramanujam 1986; Farris et al. 2010; Wang et al. 2015; Haupt and Padayachee 2016). Yet, the significance of financial performance, and its description and measurement are extensively recognized by Campbell (1977); Venkatraman and Ramanujam (1986); Sun (2000); Farris et al. (2010) and Matar and Eneizan (2018). For example, Venkatraman and Ramanujam (1986) explained that the financial performance of construction business must be closely monitored. Moreover, different concepts have been presented for financial performance, for example, Sun (2000) argued that financial performance encompasses profitability and liquidity. Allen and Helms (2006), Hooley and Lynch (1985), Ramanchandra and Rotimi (2011) and Tucker et al. (2015) identified that the component of financial performance include: productivity; sufficient cash flow; leverages; market share; order value; and meeting customer and employee satisfaction. Alfan and Zacharia (2013) argued that the major construction business performance measures are profitability, productivity, cash flow, liquidity, efficiency, adaptability, market share and leverage. Norris (1990) concluded that financial performance are enhancements to financial increase. Naoum (2003) and Soetanto et al. (2001) maintained that financial performance is the basis of running a construction business. The concepts of financial performance as presented by these studies indicate that it can be used to measure the success of the construction company within a given time and serve as input for the performance improvement of an organization to deal with market challenges.

\subsection{Financial Performance Indicators}

Extant literature and organizational effectiveness framework (Omondi-Ochieng 2018) suggests that there are six major financial performance indicators, namely: (1) profitability; (2) sufficient cash flow; (3) liquidity; (4) working capital turnover; (5) leverage; and (6) firm size. Each warrants further elucidation.

\subsubsection{Profitability}

Profitability represents a foremost focus of concern for construction stakeholders in their investment choices. Profits are mostly consequential from operational and nonoperational profits (Gschwandtner 2005; Panayiotis 2018). Operational profit is a derivative from the construction organization's project activities, whereas the non-operational profit is from the enhanced cash management, income accrued from other areas and savings from insurance plans (Ballantine et al. 1993; Moel 2014; Tucker et al. 2015; Panayiotis 2018). Thus, gross profit margin and net profit margin are indicators used for measuring profitability (Patel 2014; Panayiotis 2018). Profitability serves as a company's capability to produce gross and net income from the project activity conducted within an accounting period (Jónsson 2007; Moel 2014). Construction companies depend on retaining profits for growth to avoid external lenders retaining a stake in the firm, which reduces the profitability-growth connection. Higher dividend payments portray better prospects of a company thus, investors are encouraged to buy stock to market their companies (Moel 2014). More profitable construction companies increase their market share and have access to external finance, which stimulates business growth, while the growth of less profitable competitors will decline (Coad and Hölzl 2010; Obert and Olawale 2010). Measuring construction organizational performance in relation to economic profitability has the benefit of reducing measurement uncertainty (Phua 2006). This corroborates proven research standards that use profitability to reveal construction organizational performance thus, profitability is inextricably linked to healthier business performance (McGahan and Porter 1997; Vijayakumar and Tamizhselvan 2010).

\subsubsection{Sufficient Cash Flow}

Sufficient cash flow represents the lifeblood of an organization because without it, unresolved financial obligations cannot be met (Almeida et al. 2004; Arafat and Skaik 2016; 
Omopariola et al. 2019a). Sufficient cash flow is essentially determined by the difference between income received from payment of work and expenditure. Concomitantly, for expenditure items to be covered, a construction organization needs to have sufficient working capital to pay its creditors, suppliers, sub-contractors and employees, and may rely on clients' payments (Omopariola et al. 2017). Having sufficient cash to meet general expenses is a necessity to stimulate successful financial performance in construction projects and organizations (Omopariola et al. 2019b). According to Habib and Huang (2019), construction organizations, which have sufficient cash flow and know-how to manage cash, invest more in projects, as it attracts the attention of major stakeholders and brings about firms' growth opportunity. The converse is also true (Graham and Harvey 2001). Adequate cash flow intensifies the contractor's profit and ensures that the project owners obtain value for money in terms of cost, time, performance and sustainability, and could mean the difference between organizational success or insolvency (Lowe and Moroke 2010). As a reflection of a project and construction organization's financial performance (prior to contract completion and final account settlement), sufficient cash flow serves as a key indicator of that contracting organization's financial strength, due to its impacts on both performance and profitability (Tam 2002; Naoum 2003; Beatham et al. 2004).

\subsubsection{Liquidity}

The construction industry functions in an extremely modest environment and contractors cannot survive without resourceful management (Liu et al. 2009). Consequently, contractors are prompted to introduce low profit margins in tender bids to compete within the industry (Mahamid 2012); a strategy which inadvertently impacts upon their liquidity (Adjei et al. 2018). Research has revealed that a shortage of liquidity is a key problem triggering project failure or business insolvency (Al-Issa and Zayed 2007). This is because, liquidity assesses whether an organization's capability to meet their short-term liabilities consequently, their constituents an absolute key resource for construction companies (Liu et al. 2009; El-Kholy 2014; Adjei et al. 2018). Moreover, a contractor's liquidity is indispensable in the execution of several construction projects concurrently (Nesan 2006). Liquidity largely determines the quantity of a construction firm's profit, which also affects the value of shareholders' wealth (Ben-Caleb 2008). To survive in an increasingly competitive global market, a company must remain liquid to preserve a good credit rating and maintain goodwill in the market-essential ingredients that prevent insolvency (Bhavet 2011; Egbide et al. 2013).

\subsubsection{Working Capital Turnover}

Working capital turnover is a key facet of financial management, which every commercially oriented construction company must practice (Pandey 2005; Panigrahi 2014). Remarkably, working capital elements deal with the company's liquidity and are therefore, vital for efficient and effective operations and sustainable growth (Enyi 2006). Construction company's turnover/order value is a vital measure for deciding if a company is a micro, small, medium, or large enterprise (Ekpenyong and Nyong 1992; European Commission 2015). According to Armstrong (2006), turnover is the volume of contracts carried out by construction firms, habitually rated per year of its operation. Working capital turnover is a measure in relation to revenue availability to satisfy their organization differences in current assets and liabilities (Patel 2014; Tucker et al. 2015; Khantimirov 2017).

\subsubsection{Leverage}

Leverage is a financial management term that describes a company's risk profile, ability to repay debts and ability to take advantage of new opportunities. Al-Momani and Obeidat (2017) posit that financial leverage has a robust influence on the achievements of most construction companies. Leverage relates to the available total liabilities and current assets of an organization (Voulgaris et al. 2003; Gill and Mathur 2011; Ahmad et al. 2015). Essentially, leverage denotes the ability to incur debt or borrow funds to finance the 
purchase of a company's assets, or the extent to which a construction company employs borrowed money (Gill and Mathur 2011). A construction company that has more leverage is more profitable (Larry and Stulz 1995; Moghadam and Jafari 2015). Leverage therefore assists an organization to boost the rate of revenue by making a higher profit on borrowed money than the cost of using that money (Al-Momani and Obeidat 2017).

\subsubsection{Firm Size}

Winch (2010) states that the indicators of financial performance increase with the firm's size. For example, Pervan and Visic (2012) discovered that a construction firm's market share as a substitute for its size plays a substantial role in amplifying its comparative performance. In large firms, Etale et al. (2016) linked market share with higher profits as a means of improving organizational performance. Construction organization's function in a multifaceted and disjointed construction business setting where diverse projects and organizations display exceptional features entangled with the constant varying difficulties of stakeholders' constituting diverse investors, owners, consulting professions and contractual arrangements (CIDB 2012). This inherent complexity and multifaceted character of the construction business environment requires organizations to diversify their project portfolio to achieve and attain financial success in a competitive market (Ibrahim et al. 2010; Adamu et al. 2011). As the reputational capital of any firm and their shareholders serves as a crucial driver of good financial performance and their wealth maximization (Okpamen and Ogbeide 2020).

Construction organization sizes are typically classified into small, medium and large: where small and medium organizations can be further granulated into very small, small and medium organization (Australian Bureau of Statistic 2014; National Small Business Amendment Act No. 26 of 2003 2003). Small and medium organizations represent the activity trading businesses that employ less than 20 to about 100 employees (Australian Bureau of Statistic 2014; National Small Business Amendment Act No. 26 of 2003 2003). Small and medium organizations are habitually owner-managed and are expected to be: functioning from business premises; tax registered; and able to meet other prescribed registration required (Department of Trade and Industry, DTI 1995; Berry et al. 2002; Jewell et al. 2005; Rebello 2005). They employ skilled people to undertake the construction work required (Shakantu et al. 2006; Shakantu and Kajimo-Shakantu 2007). While the large construction organization may employ more than 99 employees (Australian Bureau of Statistic 2014; National Small Business Amendment Act No. 26 of 2003 2003). Large organizations gain firm recognition as their market liquidity serves as driving force that makes them relevant through export sales in international markets-this differentiates them from small and medium construction organizations (Dahlquist and Robertsson 2001).

\section{Research Method}

A pragmatist philosophical stance was adopted (cf. Ellis et al. 2021; Edwards et al. 2021) and deductive reasoning (cf. Ogunsanya et al. 2019; Edwards et al. 2020; Sing et al. 2021) to investigate the phenomena under investigation. Specifically, and from an operational perspective, a five-stage waterfall process was adopted viz: literature was used to inform the financial indicators and their measurement; a pilot study to test the data collection instrument; sample selection was undertaken to ensure that the participants could add credible input into the research; data collection; and data analysis. This iterative approach (and variants of it) towards building a cogent scientific narrative has been widely utilised within scientific literature (cf. Newman et al. 2020; Smith et al. 2021; Posillico et al. 2021; Burton et al. 2021; Bayramova et al. 2021) and this gives valid justification for its adoption in the present study. The indicators that are used to assess the construction organizations' level of financial performance are listed in Table 1. 
Table 1. Indicators for assessing financial performance of construction organizations.

\begin{tabular}{|c|c|c|}
\hline Indicators & Formula & References \\
\hline Gross Profit Margin & $\frac{\text { revenue-direct cost of work }}{\text { revenue }}$ & \multirow{7}{*}{$\begin{array}{l}\text { (Winch 2010; Ibrahim et al. 2010; } \\
\text { Gunhan and Arditi 2005; Jaring 2009; } \\
\text { Loo et al. 2013; Musah et al. 2018; } \\
\text { Mahamid 2012; Moel 2014; } \\
\text { Patel 2014; Sliwoski 2018) }\end{array}$} \\
\hline Net Profit Margin & $\frac{\text { gross profit-indirect costs }}{\text { revenue }}$ & \\
\hline Cash Flow & income-expenditures & \\
\hline Liquidity & $\frac{\text { current assets }}{\text { current liabilities }}$ & \\
\hline Leverage & $\frac{\text { total liabilities }}{\text { current assets }}$ & \\
\hline Working Capital Turnover & $\frac{\text { revenue }}{\text { current assets-current liabilities }}$ & \\
\hline Firm Size & $\begin{array}{l}\text { Large companies-companies with }>99 \text { employees } \\
\text { Medium companies-employees ranging from } 50 \text { to } 99 \\
\text { Small companies - with }<49 \text { employees }\end{array}$ & \\
\hline
\end{tabular}

Construction organizations with high-level business executives and the top-level managers (i.e., Construction Industry Development Board (CIDB) grade 7-9) were targeted for this study. This approach helped to secure credible and verifiable financial information. A pilot study was conducted to test the data collection instrument. Feedback given was mainly used to improve the quality of expression and clarify questions posed. The final revised questionnaire was distributed to 2103 grade 7-9 companies listed in the CIDB database. Criteria delineated for verifying the contractors' financial credibility included: availability of financial statements; stamped business bank statements; proof of financial sponsorship; audited financial statements; financial track records; financial history; the financial capability of $\geq \mathrm{R} 40$ million; annual turnover of $\geq \mathrm{R} 20$ million; work capability of $\geq \mathrm{R} 9$ million; and available capital of $\geq \mathrm{R} 4$ million.

A total of 32 companies were able to give the required financial information which was confirmed by cross referencing against the financial details published by the CIDB and on their individual company websites. The sample companies were contacted to nominate a representative that would supply the required data for this research. The questionnaire adopted elicited information on the company's profile and financial details-such as: total revenue; direct cost of work; total indirect cost; total income; total expenditure; total current assets; and total liabilities.

Data analysis was conducted by using the parameters elicited from the companies' representative to: (1) ascertain if the financial performance indicators proposed by this study are applicable in the construction organizations; and (2) determine the values of the financial performance indicators. The formulas developed for the financial performance indicators were used to determine the values of the financial performance indicators. Post hoc Tukey's honest significant difference (HSD) was used to test for significant differences in the indicators.

\section{Results}

\subsection{Profile of Respondents}

Table 2 presents the demographic profile of respondents. Concerning the respondents educational backgrounds, Table 1 shows that $54.13 \%$ (frequency $(f)=17$ ) had a bachelor's degree, $25.00 \%(f=8)$ had a higher diploma, $15.62 \%(f=5)$ had a diploma with Grade 12 , and $6.25 \%(f=2)$ had a N4-6/NTC 4-6 Certificate. Regarding job position, directors constituted $68.75 \%(f=22)$ of the sample; management constituted $28.13 \%(f=9)$; and technical officers constituted $3.12 \%(f=1)$. For professional status: construction managers predominated at $53.12 \%(f=17)$, while engineers $=28.13 \%(f=9)$, quantity surveyors $15.63 \%(f=5)$ and architects accounted for, $3.12 \%(f=1)$ of the total respondents. Regarding the years of experience $40.62 \%(f=13)$ of the respondents had gathered $11-15$ years; $34.38 \%$ $(f=11)$ had gathered $16-20$ years; and $25.00 \%(f=8)$ had gathered $>21$ years of working experience. These results suggest that the respondents possessed sufficient knowledge, 
qualifications, and experience to understand the questions posed and provide useful and complete information.

Table 2. Profile of respondents.

\begin{tabular}{|c|c|c|}
\hline Answer Choices & Response (Frequency) & Responses Percent \\
\hline & \multicolumn{2}{|c|}{ Educational Backgrounds of the Respondents } \\
\hline Bachelor's Degree or Higher & 17 & $53.13 \%$ \\
\hline Higher Diploma (Technicon/University of Tech) & 8 & $25.00 \%$ \\
\hline Certificate-Diploma with Grade12 & 5 & $15.62 \%$ \\
\hline N4-6/NTC 4-6/Certificate-Diploma with lowere than Grade 12 & 2 & $6.25 \%$ \\
\hline Total & 32 & $100.00 \%$ \\
\hline & & Designations of the Respondents \\
\hline Director Cadre & 22 & $68.75 \%$ \\
\hline Management Cadre & 9 & $28.13 \%$ \\
\hline Technical Officer Cadre & 1 & $3.12 \%$ \\
\hline \multirow[t]{2}{*}{ Total } & 32 & $100.00 \%$ \\
\hline & & Professions of the Respondents \\
\hline Construction Manager & 17 & $53.12 \%$ \\
\hline Engineer & 9 & $28.13 \%$ \\
\hline Quantity Surveyor & 5 & $15.63 \%$ \\
\hline Architect & 1 & $3.12 \%$ \\
\hline \multirow[t]{2}{*}{ Total } & 32 & $100.00 \%$ \\
\hline & Years o & of Experience of the Respondents \\
\hline $11-15$ years & 13 & $40.62 \%$ \\
\hline $16-20$ years & 11 & $34.38 \%$ \\
\hline 21 years and above & 8 & $25.00 \%$ \\
\hline Total & 32 & $100.00 \%$ \\
\hline
\end{tabular}

Table 3 presents the profile of the participants' employer. Profiles, such as the grade of the organization on the CIDB register of contractors, age of the organization, size of the organization, location and the number of projects handled by the company in the previous five years were analyzed. In terms of the organizations' CIDB grade, it was found that all the companies specialized in either general building construction or civil engineering construction. For companies that specialized in general building construction, $44.44 \%$ $(f=4)$ of those companies were listed on Grade 7, $11.12 \%(f=1)$ on Grade 8 and $44.44 \%$ $(f=4)$ on Grade 9. For companies that specialized in civil engineering construction, $40.00 \%$ $(f=4)$ were listed on Grade 7, 50.00\% $(f=5)$ on Grade 8 and $10.00 \%(f=1)$ on Grade 9 . For companies that specialized in both general building construction and civil engineering construction, 38.46\% $(f=5)$ were listed on Grade 7, 30.77\% $(f=4)$ on Grade 8 and 30.77\% $(f=4)$ on Grade 9. With reference to the age of these companies, $6.25 \%(2)$ had been in operation for $<5$ years, while $12.50 \%(f=4), 12.50 \%(f=4), 43.75 \%(f=14), 25.00 \%(f=8)$, had been in operation for 6-10 years, 11-15 years, $16-20$ years and >21years respectively. Companies with $<20$ employees accounted for $43.75 \%(f=14)$ of the respondents, while those with 20-49 and 50-59 employees accounted for $18.75 \%(f=6)$ and $15.62 \%(f=5)$, respectively. Only $9.38 \%(f=3)$ of the companies had 100-199 employees, and $12.50 \%$ $(f=4)$ had $>200$ employees. Pertaining to the province where the head office is located, most of the companies were located in Gauteng (31.25\%: $f=10)$, Kwazulu-Natal (51.63\%: $f=5$ ), Western Cape (12.50\%: $f=4)$, Eastern Cape (9.37\%: $f=3$ ), and Limpopo $(9.37 \%$ : $f=3)$. Only $43.75 \%(f=14)$ of these companies had handled projects worth R $50 \mathrm{M}, 31.25 \%$ $(f=10)$ of these companies had handled projects worth R $50-200 \mathrm{M}$, and $25.00 \%(f=8)$ had handled projects worth $>\mathrm{R} 200 \mathrm{M}$. This result suggests that the respondents' employer was viable and capable of providing the respondents with appropriate experience. 
Table 3. Profile of companies.

\begin{tabular}{|c|c|c|}
\hline Answer Choices & Responses (Frequency) & Responses Percentage \\
\hline \multicolumn{3}{|c|}{$\begin{array}{c}\text { Class of Work and Grade of Your Company on the CIDB Register of Contractors } \\
\text { General Building Construction (GB) }\end{array}$} \\
\hline Grade 7 & 4 & $44.44 \%$ \\
\hline Grade 8 & 1 & $11.12 \%$ \\
\hline Grade 9 & 4 & $44.44 \%$ \\
\hline Total & 9 & $100.00 \%$ \\
\hline \multicolumn{3}{|c|}{ Civil Engineering Construction (CE) } \\
\hline Grade 7 & 4 & $40.00 \%$ \\
\hline Grade 8 & 5 & $50.00 \%$ \\
\hline Grade 9 & 1 & $10.00 \%$ \\
\hline Total & 10 & $100.00 \%$ \\
\hline \multicolumn{3}{|c|}{ Both General Building Construction (GB) and Civil Engineering Construction (CE) } \\
\hline Grade 7 & 5 & $38.46 \%$ \\
\hline Grade 8 & 4 & $30.77 \%$ \\
\hline Grade 9 & 4 & $30.77 \%$ \\
\hline Total & 13 & $100.00 \%$ \\
\hline \multicolumn{3}{|c|}{ Age of Company } \\
\hline Less than 5 years & 2 & $6.25 \%$ \\
\hline $6-10$ years & 4 & $12.50 \%$ \\
\hline 11-15 years & 4 & $12.50 \%$ \\
\hline $16-20$ years & 14 & $43.75 \%$ \\
\hline 21 years and above & 8 & $25.00 \%$ \\
\hline Total & 32 & $100.00 \%$ \\
\hline \multicolumn{3}{|c|}{ Company Size Defined by the Number of Employees } \\
\hline Less than 20 & 14 & $43.75 \%$ \\
\hline $20-49$ & 6 & $18.75 \%$ \\
\hline $50-99$ & 5 & $15.62 \%$ \\
\hline 100-199 & 3 & $9.38 \%$ \\
\hline More than 200 & 4 & $12.50 \%$ \\
\hline Total & 32 & $100.00 \%$ \\
\hline \multicolumn{3}{|c|}{ Province Where the Head Office is Located } \\
\hline Gauteng & 10 & $31.25 \%$ \\
\hline Kwazulu-Natal & 5 & $15.13 \%$ \\
\hline Western Cape & 4 & $12.50 \%$ \\
\hline Eastern Cape & 3 & $9.37 \%$ \\
\hline Limpopo & 3 & $9.37 \%$ \\
\hline Mpumalanga & 2 & $6.25 \%$ \\
\hline North-west & 2 & $6.25 \%$ \\
\hline Northern Cape & 2 & $6.25 \%$ \\
\hline Free State & 1 & $3.13 \%$ \\
\hline Total & 32 & $100.00 \%$ \\
\hline \multicolumn{3}{|c|}{ Number of Construction Projects Handled by the Company in the Last Five Years } \\
\hline$<\mathrm{R} 50 \mathrm{M}$ & 14 & $43.75 \%$ \\
\hline R50 M-R200 M & 10 & $31.25 \%$ \\
\hline$>\mathrm{R} 200 \mathrm{M}$ & 8 & $25.00 \%$ \\
\hline Total & 32 & $100.00 \%$ \\
\hline
\end{tabular}

\subsection{Analysis of the Level of Performance of the Construction Companies within a Period}

Table 4 shows the level of financial performance (e.g., leverage, liquidity, profitability, and cash flow) of selected construction companies during the five years spanning 2013-2017. The leverage index was determined by cutting up total liabilities with the current assets; the liquidity index was determined by cutting up current assets with the current liabilities; the cash flow index was determined by deducting total expenditures from total income; and the profitability index was estimated in two parts comprising of gross profit margin and net profit margin. The gross profit margin was determined by deducting the total direct cost of work from the total revenue and cutting up the residue with the total revenue. The net profit margin was determined by deducting the total indirect costs of 
work from the total gross profit and cutting up the residue with the total revenue. Table 4 presents participants' employers' financial information. The respondents also provided other information, such as construction company revenue, total revenue and the period. The significance difference in the results of the analysis as provided by the indicators was tested by using post hoc Tukey's HSD (refer to Table 5).

Table 4 reveals that the construction companies fell into three categories, namely general building construction (GB), civil engineering construction (CE), and general building and civil engineering construction (GB and CE). Moreover, sample companies were listed in three of the CIDB's register of contractor (ROC) grades (Grade 7, 8 and 9) and divided into three firm sizes (small, medium and large) for a better explanation.

Among sample participants, only one had a total revenue of R2.6 billion between 2013 and 2017. This company was a large firm, listed in Grade 9 of the CIDB ROC and specialized in civil engineering construction. Using a cut-off value of $\mathrm{R} 100$ million based on the average total revenue for the construction companies, only nine other construction companies met this criterion alongside the two identified companies with total revenue in the range of billions of Rands. Among these nine construction companies, four specialized in general building and civil engineering construction ( $R 213$ million, medium firm listed in Grade 8 of CIDB ROC, R 188 million, large firm, and grade 9, R 423.9 million, large firm and grade 9, and R 102.5 million large firm and grade 9 of CIDB ROC). Three of the construction companies specialized in general building construction ( $\mathrm{R} 275$ million, small firm and grade 7, R 550 million, medium firm and grade 7, and R 153 million, large firm and grade 9). Only one of the construction companies specialized in civil engineering construction and had total revenue of (R 104 million, a large firm and listed in Grade 8 of CIDB ROC).

Table 4. Analysis of the financial performance of construction organizations.

\begin{tabular}{|c|c|c|c|c|c|c|c|c|c|c|c|c|c|c|c|}
\hline $\mathrm{CW}$ & GD & FS & TR & DCW & TC & TI & TE & TA & TL & GM & NM & $\mathrm{CF}$ & LQ & LV & WT \\
\hline $\mathrm{CE}$ & 7 & Large & $\mathrm{R} 124.8 \mathrm{M}$ & 13.2 & 0.1 & 12.2 & 19.3 & 22.7 & 26 & 0.89 & 0.01 & -7.1 & 0.87 & 1.15 & -36.71 \\
\hline$G B$ and $C E$ & 8 & Medium & R213M & 172 & 35 & 15 & 137 & 8 & 2.1 & 0.19 & -0.16 & -122 & 3.80 & 0.26 & 1.65 \\
\hline GB and CE & 9 & Large & R188M & 11 & 48.2 & $\mathrm{R} 1.2 \mathrm{~B}$ & 90 & 1.2 & 1.6 & 0.94 & -0.25 & 1110 & 0.75 & 1.33 & 2.11 \\
\hline $\mathrm{CE}$ & 8 & Medium & R60M & 40 & 12 & 6.7 & 3.2 & 11.5 & 4.2 & 0.33 & -0.19 & 3.5 & 2.73 & 0.36 & -7.22 \\
\hline GB and CE & 9 & Large & $\mathrm{R} 12 \mathrm{M}$ & 40 & 50 & 58.6 & 56.4 & 10 & 15 & -2.33 & -4.36 & 2.2 & 0.66 & 1.5 & 0.25 \\
\hline GB & 9 & Large & 27 & 17 & 100 & 8 & 8 & 1.3 & 1.5 & 0.37 & -3.68 & 0 & 0.86 & 1.15 & 4.02 \\
\hline GB & 8 & Large & 38.2 & 36.1 & 0.5 & 28.7 & 28.2 & 13.3 & 25.3 & 0.05 & -0.01 & 0.5 & 0.52 & 1.90 & 2.56 \\
\hline GB & 7 & Medium & 33 & 25 & 5 & 4.5 & 2.7 & 32.9 & 29.6 & 0.24 & -0.14 & 1.8 & 1.11 & 0.89 & -1.09 \\
\hline CE & 7 & Small & 36.5 & 4.3 & 0 & 12.5 & 6.3 & 19 & 8 & 0.88 & 0.024 & 6.2 & 2.37 & 0.42 & -2.87 \\
\hline CE & 7 & Small & 6.2 & 4.3 & 0.3 & 300 & 275 & 6.7 & 4.9 & 0.30 & 0.01 & 25 & 1.36 & 0.73 & 0.023 \\
\hline CE & 8 & Medium & 57.7 & 48.7 & 8.9 & 22.2 & 24.9 & 83.3 & 64.6 & 0.15 & -0.15 & -2.7 & 1.28 & 0.77 & -0.98 \\
\hline GB and CE & 7 & Large & 20 & 12 & 0.3 & 859.1 & 456.1 & 11.5 & 4 & 0.40 & 0.01 & 403 & 2.87 & 0.34 & 0.04 \\
\hline $\mathrm{CE}$ & 8 & Large & 22 & 4 & 6 & 56.5 & 48.9 & 8.1 & 6.4 & 0.81 & -0.23 & 7.6 & 1.26 & 0.79 & 0.53 \\
\hline GB and CE & 8 & Large & 9.1 & 2.7 & 2.1 & 107 & 97 & 83.1 & 72.1 & 0.70 & -0.15 & 10 & 1.15 & 0.87 & 0.65 \\
\hline GB and CE & 8 & Large & 14 & 7 & 2 & 90.6 & 29.5 & 29.1 & 19 & 0.50 & -0.11 & 61.1 & 1.53 & 0.65 & 35 \\
\hline GB & 7 & Small & 275 & 189 & 40 & 98.9 & 78.8 & 10 & 18 & 0.31 & -0.14 & 20.1 & 0.55 & 1.8 & 3.99 \\
\hline CE & 9 & Large & $\mathrm{R} 2.6 \mathrm{~B}$ & 100 & 26 & 83.5 & 80 & $\mathrm{R} 8.6 \mathrm{~B}$ & R7.3B & 0.96 & -0.01 & $\begin{array}{l}20.1 \\
3.5\end{array}$ & 1.17 & $\begin{array}{l}1.0 \\
0.84\end{array}$ & -0.30 \\
\hline GB and CE & 7 & Medium & 11 & 7 & 3 & $\mathrm{R} 1.4 \mathrm{~B}$ & R1.3B & 40 & 23 & 0.36 & -0.23 & 100 & 1.73 & 0.57 & 0.01 \\
\hline$G B$ and $C E$ & 7 & Small & 56.5 & 30.5 & 18.4 & 44.1 & 43.5 & 45 & 53 & 0.46 & -0.31 & 0.6 & 0.84 & 1.17 & -37.66 \\
\hline GB & 7 & Medium & 67 & 48 & 11 & 65.3 & 40.9 & 12 & 15 & 0.28 & -0.15 & 24.4 & 0.8 & 1.25 & 2.31 \\
\hline CE & 8 & Large & 104 & 86 & 10.5 & 120 & 150 & 17 & 11 & 0.17 & -0.09 & -30 & 1.54 & 0.64 & 0.78 \\
\hline GB and CE & 8 & Large & 85 & 52 & 28 & 110.1 & 84.5 & 75 & 24 & 0.38 & -0.32 & 25.6 & 3.125 & 0.32 & 8.94 \\
\hline GB & 9 & Large & R1.4B & $\mathrm{R} 1.2 \mathrm{~B}$ & R0.2B & 95 & 80.9 & 80 & 71 & 0.14 & -0.14 & 14.1 & 1.13 & 0.89 & 1555.55 \\
\hline GB & 7 & Medium & 550 & 6 & 4 & 20 & 11 & 28.5 & 17.6 & 0.98 & -0.01 & 9 & 1.61 & 0.61 & -31.42 \\
\hline GB and CE & 9 & Large & 423.9 & 311.6 & 39.8 & 30.2 & 9.4 & $\mathrm{R} 2.7 \mathrm{~B}$ & 24.4 & 0.26 & -0.09 & 20.8 & 110.65 & 0.01 & -0.15 \\
\hline GB & 9 & Large & 76 & 65.4 & 0.8 & 22 & 20.3 & 86.6 & 75.3 & 0.13 & -0.01 & 1.7 & 1.15 & 0.86 & -1.14 \\
\hline GB & 9 & Large & 153 & 153 & 46 & 14.4 & 10.4 & 32.7 & 18.4 & 0.00 & -0.30 & 4 & 1.77 & 0.56 & -6.86 \\
\hline GB and CE & 7 & Medium & 49.4 & 37.4 & 21 & 26 & 24 & 50.6 & 26.4 & 0.24 & -0.42 & 2 & 1.91 & 0.52 & -1.85 \\
\hline CE & 7 & Medium & 99 & 78.5 & 48 & 37.4 & 22.9 & 25.7 & 25 & 0.20 & -0.48 & 14.5 & 1.02 & 0.97 & -35.35 \\
\hline CE & 8 & Large & 29.3 & 11.4 & 4.9 & 29.1 & 25.2 & 25 & 28 & 0.61 & -0.14 & 3.9 & 0.89 & 1.12 & 146.50 \\
\hline GB and CE & 7 & Medium & 94.6 & 78.8 & 4.3 & 46.3 & 27.5 & 2.5 & 7.1 & 0.16 & -0.04 & 18.8 & 0.35 & 2.84 & 3.78 \\
\hline$G B$ and $C E$ & 9 & Large & 102.5 & 85.8 & 14.8 & 85.5 & 67.4 & R1.4B & 71 & 0.16 & -0.14 & 18.1 & 19.71 & 0.05 & -0.07 \\
\hline
\end{tabular}

$\mathrm{GB}=$ general building construction; $\mathrm{CE}=$ civil engineering construction; $\mathrm{CW}=$ class of work $\mathrm{GD}=\mathrm{CIDB}$ grade; $\mathrm{FS}=$ firm size; $\mathrm{TR}=$ total revenue; $\mathrm{DCW}=$ direct cost of work; $\mathrm{TC}=$ total indirect costs; $\mathrm{TI}=$ total income; $\mathrm{TE}=$ total expenditure; $\mathrm{TA}=$ total current asset; $\mathrm{TL}=$ total liabilities; $\mathrm{GM}=$ gross profit margin; $\mathrm{NM}=$ net profit margin; $\mathrm{CF}=$ cash flow; $\mathrm{LQ}=$ liquidity; $\mathrm{LV}=$ leverage; $\mathrm{WT}=$ working capital turnover. 
Table 5. Analysis of significant difference of the financial indicators using post hoc Tukey's HSD.

\begin{tabular}{|c|c|c|c|c|}
\hline Indicators & Firm Size & Tukey's HSD & Significance & Interpretation \\
\hline \multirow{3}{*}{ Gross Profit Margin } & Large $\Theta$ Medium & 0.05 & $P=0.000$ & Significant \\
\hline & Large $\Theta$ Small & 0.01 & $P=0.000$ & Significant \\
\hline & Medium $\Theta$ Small & 0.06 & $P=0.000$ & Significant \\
\hline \multirow{3}{*}{ Net Profit Margin } & Large $\Theta$ Medium & 0.15 & $P=0.000$ & Significant \\
\hline & Large $\Theta$ Small & 0.00 & $P=0.000$ & Significant \\
\hline & Medium $\boxminus$ Small & 0.15 & $P=0.000$ & Significant \\
\hline \multirow{3}{*}{ Cash Flow } & Large $\boxminus$ Medium & 5.90 & $P=0.000$ & Significant \\
\hline & Large $\Theta$ Small & 0.90 & $P=0.000$ & Significant \\
\hline & Medium $\Theta$ Small & 5.00 & $P=0.000$ & Significant \\
\hline \multirow{3}{*}{ Liquidity } & Large $\leftrightarrows$ Medium & 3.00 & $P=0.000$ & Significant \\
\hline & Large $\Theta$ Small & 0.30 & $P=0.000$ & Significant \\
\hline & Medium $\Theta$ Small & 2.90 & $P=0.000$ & Significant \\
\hline \multirow{3}{*}{ Leverage } & Large $\leftrightarrows$ Medium & 0.90 & $P=0.000$ & Significant \\
\hline & Large $\Theta$ Small & 0.70 & $P=0.000$ & Significant \\
\hline & Medium $\boxminus$ Small & 0.20 & $P=0.000$ & Significant \\
\hline \multirow{3}{*}{ Working Capital Turnover } & Large $\leftrightarrow$ Medium & 2.00 & $P=0.000$ & Significant \\
\hline & Large $\Theta$ Small & 1.70 & $P=0.000$ & Significant \\
\hline & Medium $\Theta$ Small & 0.30 & $P=0.000$ & Significant \\
\hline
\end{tabular}

Six of the contractors had a total direct cost of work exceeding R 100 million. Three of these companies specialized in general building construction with a direct cost of work (DCW) of R 189 million, a small firm listed in Grade 7 of CIDB ROC, R 1.2 billion, a large firm listed in Grade 9 of CIDB ROC, and R 153 million, a large firm listed in Grade 9 of CIDB ROC, respectively. Two of these companies specialized in general building and civil engineering works and had a DCW of R 172 million- medium-firm listed in Grade 8 of CIDB ROC, and R 311.6 million, a large firm listed in Grade 9 of CIDB ROC). One of these companies specialized in civil engineering construction and had a DCW of R 100 million, a large firm listed in Grade 9 of CIDB ROC).

For total indirect costs, only two construction companies that specialized in general building construction had a total indirect cost $>$ R 100 million ( $R 100$ million, a large firm listed in Grade 9, and R0.2 billion a large firm listed in Grade 9 of CIDB ROC). Table 4 shows that seven construction companies had total income $>$ R 100 million. Five of these companies specialized in general building and civil engineering construction ( $\mathrm{R} 1.2$ billion, a large firm listed in Grade 9 of CIDB ROC; R 859.1 million, a large firm listed in Grade 7; R 107 million, a large firm listed in Grade 8; R 1.4 billion, a medium firm listed in Grade 7; and R 110 million. a large firm listed in Grade 8 of CIDB ROC). None of the companies specialized only in general building construction, while the remaining two companies specialized in civil engineering construction (R 120 million, a large firm listed Grade 8, and R 300 million, a small firm and Grade 7 of CIDB ROC). Concerning the total expenditure of the construction companies, Table 3 shows that five construction companies expended above R 100 million in the previous five years. Three of these companies specialized in general building and civil engineering construction ( $\mathrm{R} 137$ million, a medium firm listed in Grade 8 of CIDB ROC; R 456.1 million, a large firm listed in Grade 7; R 1.3 billion a medium firm listed in Grade 7 of CIDB ROC). The other two specialized in civil engineering construction (R 275 million, a small firm listed in Grade 7 of CIDB ROC; and R 150 million, a large firm listed in Grade 8 of CIDB ROC).

Regards the total current assets and total liabilities of the construction companies, Table 4 reveals that three construction companies had acquired assets $>$ R 100 million, while 
only one organization had a total liability of $>$ R 100 million. Two of the three construction companies with total current assets $>$ R 100 million specialized in general building and civil engineering construction ( 2.7 billion, a large firm and Grade 9, and R 1.4 billion, a large firm listed in Grade 9 of CIDB ROC), and the other, in civil engineering construction ( $R$ 8.6 billion a large firm listed in Grade 9 of CIDB ROC). Organization with specialization in civil engineering construction ( $\mathrm{R} 7.3$ billion, a large firm and grade 9 ) had a total liability $>$ R 100 million.

Table 4 reveals that all 32 construction companies studied had a positive gross profit margin, except one of the organizations with a negative gross profit margin of -2.33 . This organization was listed in Grade 9, large firm of CIDB ROC with specialization in general building and civil engineering construction. Regarding the net profit margin, only four companies had a positive net profit margin. Three of these companies specialized in civil engineering construction with a net profit margin of 0.01 , a large firm listed in Grade 7 of CIDB ROC; 0.024 a small firm listed in Grade 7 of CIDB ROC; and 0.01 a small firm listed in Grade 7 of CIDB ROC, while one organization, which specialized in general building and civil engineering construction, had a net profit margin of 0.01 a large firm listed in Grade 7 of CIDB ROC. For cash flow, liquidity, and leverage; only four construction companies had negative cash flow, none had negative liquidity or negative leverage. Among the four construction companies with negative cash flow, three specialized in civil engineering construction with a negative cash flow of -7.1 , a large firm listed in Grade 7 of CIDB ROC; -2.7 a medium firm listed in Grade 8, and -30, a large firm listed in Grade 8 of CIDB ROC, while one company specialized in general building and civil engineering construction and had a negative cash flow of -122 , a medium firm listed in Grade 8 of CIDB ROC.

Pertaining to the working capital turnover of the construction companies, 14 companies had negative working capital turnover. These companies also incur higher personnel costs, administration costs, security costs and production costs such as costs of labour, materials and plant. Furthermore, the results imply that Grade 8 large firms of CIDB ROC, which specialize in general building and civil engineering construction receive higher financial rewards from their works and investments. They also expend huge amounts of money on their projects. The results also suggest that Grade 9 large construction companies with specialization in general building and civil engineering construction have more cash and other assets that can be converted to cash. In addition, construction companies with specialization in civil engineering construction have more leverage. All the construction companies, irrespective of their area of specialization, CIDB grade and/or firm size were found to have positive gross profit margins. This suggests that all the contractors are financially stable despite their liabilities and direct cost of work. Small construction companies with specialization in civil engineering construction were found to have a positive net profit margin. This suggests that civil engineering construction is more profitable than general building construction because construction companies specializing in civil engineering construction can extract more profit from their total revenue compared to those specializing in general building construction. Large construction companies specializing in civil engineering construction were found to have a higher negative cash flow. This implies that the work of civil engineering affects the liquidity of construction companies more than other types of projects because it requires the transfer of huge amounts of money into and out of the construction companies. These civil engineering companies were also found to have higher working capital to fund day-to-day operations.

\section{Discussion of Findings}

It emerged that large firms with specialization in general building and civil engineering construction have higher income, higher positive leverage, and higher positive cash flow. Large firms with specialization in civil engineering construction have higher positive liquidity and higher negative cash flow. Small firms with specialization in civil engineering construction were found to have higher profitability. It could be inferred from these findings that large firms have higher income, higher positive leverage, higher 
positive liquidity and higher positive cash flow because large firms are more organized, have greater access to funding and are preferred for large projects that can generate larger profits. Large firms have a structure and staff strength that support the maximization of creativity, efficiency and productivity. With these attributes of large firms, the collective efforts of employees can be pooled and focused on the organizational needs and objectives. These findings are aligned to findings of earlier studies by Arafat and Skaik (2016), Rachmawati and Triatmoko (2007) and Lowe and Moroke (2010) which concur with this explanation. Another explanation for the good financial performance of large firms could be that large firms have the financial resources to diversify. Having multiple areas of specialization or diversification into new areas enables better utilization of financial resources; such an approach represents a means of surviving and thriving in all manner of market conditions. More importantly, it helps companies to enhance their non-substitutable and valuable resources to retain a competitive advantage and to realize greater financial benefits (cf. Adamu et al. 2011; Oyewobi 2014; Etale et al. 2016; Soewarno and Tjahjadi 2020).

Regarding the good financial performance of large firms with specialization in civil engineering construction - the findings suggests that because civil engineering projects provide infrastructures that trigger economic growth, they have huge financial implications for companies that specialize in them. This will be the case, most especially if these companies effectively manage the projects. Effective management of civil engineering projects improves the likelihood of generating huge financial benefits from projects managed. This explanation corroborates the conclusion by Tebaldi (2014), which implied that civil engineering construction projects have higher construction costs, require specialist sub-contractors, and require a stable flow of funds because of their numerous activities (Omopariola et al. 2017). It was surprising to find small firms with specialization in civil engineering construction also have relatively high profitability. This suggests that small firms have lower expenses because of their staff strength and financial obligations. It also means that small firms are more focused on profitability because of the need to grow. It could also be inferred that small firms, which concentrate on civil engineering construction as their sole area of specialization, have made efforts to explore new possibilities and opportunities for making profits in civil engineering construction. This clarification concurs with the findings of Neshamba (2000), Voulgaris et al. (2003), Gathenya (2012), Pervan and Visic (2012), Naikuru et al. (2016) and Okpamen and Ogbeide (2020) who proffer that, small firms and shareholder with good client relations, new expertise, reputation for quality and capital, and diversified investment will experience good financial performance and wealth maximization.

This study has contributed to theoretical knowledge and insight into how the consequences of the area of specialization impacts upon contractors' financial performance and wealth maximization of firms. Critical to this contribution is the understanding of the relationship between financial performance and types of construction companies. Also, an enhancement in the financial performance of construction organizations would assist in the growth of the local industry, which would in turn, translate into cost-effective development of the nation-given the sector's crucial role in contributing to the economy's development. The study also contributed to theoretical knowledge into how a construction company's financial performance is an indicator of their health and resilience to insolvency. Consequently, the research also has practical implications specifically, the study enables the identification of measures that can be used by both constructors and clients (e.g., indicators relating to financial performance), so that construction company performance problems in projects are reduced to the barest minimum. This research is also useful to other construction stakeholders involved in the project delivery (especially the client, individual professionals and sub-contractors), by highlighting channels of improving construction project delivery and construction organization performance in the construction industry. Better consideration of these issues will assist stakeholders, who are concerned to ascertain threats and prospects amidst their working environments, to be aware of how they can utilize their resources to attain persistent viable improvement, which is the essence of a 
competitive strategy. The construction industry functions in an extremely modest financial environment with typically low profit margins and contractors cannot survive without resourceful management.

The readiness of the respondents, and the responses obtained from them, determined the accuracy of the findings, as some of the professionals and the registered contractors did not release the financial information about their construction organizations. Such a limitation was experienced due mainly to the Privacy Acts in operation within the industry. This is a notable limitation and perhaps skewed the results accrued-where, only contractors with healthy finances participated in the work. Such would act as an advertisement for them and could accrue additional investments and contracts. One of the limitations of the method used in this study is that the choice of the professionals and contractors listed in Grades 7 to 9 of the CIDB register of contractors limits the extent to which the outcomes of the findings can be generalized, as the respondents could not be representative of all CIDB registered contractors listed in Grades 7 to 9 of South African construction organizations. Future work is therefore required to address a need to understand the nature of the financial performance of other less profitable construction businesses together with the reasons for this. The insights provided by this work will extend the understanding of financial performance indicators in use by construction organizations. Likewise, future work is required to investigate the financial performance of construction companies over a longer time period (for instance ten to 20 years). This will provide more reliable information on the financial performance of construction companies by holding constant macro-economic turbulence that invariable impacts upon company performance (even those businesses with optimal performance management strategies in place).

\section{Conclusions and Recommendations}

Hitherto, there has been no consensus on the indicators for assessing the financial performance of construction companies on construction projects. Also, there has been a dearth of concepts on the financial performance indicators for construction companies in South Africa and indeed, the wider continent of Africa. This study proposes financial performance indicators for assessing the financial performance of construction organizations and determines the level of financial performance of selected construction companies in the South African construction industry. The research was conducted using structured questionnaire survey to acquire responses from the representatives of the selected construction companies. It emerged from the study that firm size, gross profit margin, net profit margin, cash flow, liquidity, working capital turnover, and leverage are useful indicators for assessing the financial performance of construction companies and that construction companies with a strong structure, multiple areas of specialization, creative and efficient staff members, and access to funding, have a great chance of experiencing higher: income; positive leverage; positive liquidity; and positive cash flow. Similarly, construction companies with specialization in civil engineering construction and project management skills will experience higher positive liquidity and profitability.

The construction industry represents the backbone of any economy globally as the sector builds economic and social infrastructure needed to generate wealth and satisfy public demand for a good standard of living and employment opportunities. It is therefore imperative that research secures a deeper and more knowledgeable understanding of the financial machinations underpinning contractors' financial health and profitability as incidents of insolvency invariably inflate project cost-a cost that is ultimately borne by the taxpayer. Moreover, educating contractors in financial performance measurement will help them to improve internal business processes. Thus, the study recommends that construction companies with limited financial resources must make efforts to perfect their project management skills and explore opportunities for maximizing financial benefits in their area of specialization. The implication of the findings of this study (notably regarding managerial duties and financial policy) is that the management of construction firms must be conversant with financial performance indicators and their applications 
to decision-making and policies in their respective firms. Higher education institutes will have a fundamental role in ensuring that appropriate education and knowledge of financial performance management is delivered to future generations of construction and civil engineering managers. This study also recommends that construction organizations with huge financial resources should diversify into a new area of specialization to realize more financial benefits and to better utilize their financial resources.

Author Contributions: Conceptualization, E.D.O., A.W. and D.J.E.; methodology, E.D.O., A.W., D.J.E. and H.E.-G.; validation, E.D.O., A.W., D.J.E. and H.E.-G.; formal analysis, E.D.O., A.W., D.J.E. and H.E.-G.; investigation, E.D.O., A.W. and D.J.E.; data curation, E.D.O., A.W. and D.J.E.; writingoriginal draft preparation, E.D.O., A.W., D.J.E. and H.E.-G.; writing-review and editing, E.D.O., A.W., D.J.E. and H.E.-G.; supervision, A.W. and D.J.E.; project administration, E.D.O., A.W. and D.J.E. All authors have read and agreed to the published version of the manuscript.

Funding: This research was funded by the National Research Foundation (NRF) (Grant Number: 105301) and Tetfund.

Institutional Review Board Statement: The study was conducted according to an ethical protocol that was approved by Department of Construction Economics and Management, University of Cape Town.

Informed Consent Statement: Informed consent was obtained from all subjects involved in the study.

Data Availability Statement: Anonymised data is available from the corresponding author upon written request and subject to review.

Acknowledgments: The financial assistance of the National Research Foundation (NRF) (Grant Number: 105301) and Tetfund towards this research is hereby acknowledged. Opinions expressed, and conclusions arrived at, are those of the authors and are not necessarily to be attributed to the NRF and Tetfund.

Conflicts of Interest: The authors declare no conflict of interest.

\section{References}

Adamu, Nasiru, Ibrahim Khalil Zubairu, Yahya Makarfi Ibrahim, and Aliyu Makarfi Ibrahim. 2011. Evaluating the impact of product diversification on financial performance of selected Nigerian construction firms. Journal of Construction in Developing Countries 16 : 91-114.

Adjei, Emmanuel, Frank Desmond Kofi Fugar, Emmanuel Adinyira, David John Edwards, and Erika Anneli Parn. 2018. Exploring the significant cash flow factors influencing building projects profitability in Ghana. International Journal of Construction Engineering and Management 7: 35-46.

Ahmad, Nawaz, Atif Salman, and Aamir Firoz Shamsi. 2015. Impact of financial leverage on firm's profitability: An investigation from cement sector of Pakistan. Research Journal of Finance and Accounting 6: 75-80.

Alfan, Ervina, and Zarina Zacharia. 2013. Review of financial performance and distress: A case of Malaysian construction companies. British Journal of Arts and Social Sciences 12: 1-15.

Al-Issa, Ahmed, and Tarek Zayed. 2007. Project Cash Flow Factors-contractors Perspective. Paper presented at the Construction Research Congress (CRC) Conference, ASCE/CIB, Grand Bahama Island, Bahamas, May 5-8.

Allen, Richard, and Marilyn Michael Helms. 2006. Linking strategic practices and organizational performance to Porter's generic strategies. Business Process Management Journal 12: 433-54. [CrossRef]

Almeida, Heitor, Murillo Campello, and Michael Steven Weisbach. 2004. The cash flow sensitivity of cash. The Journal of Finance 59: 1777-804. [CrossRef]

Al-Momani, Mohammed Abdullah, and Mohammed Ibrahim Obeidat. 2017. Towards more understanding of the financial leverage controversy: The evidence of the industrial firms at Amman stock exchange. International Journal of Economics and Financial Issues 7: 189-98.

Amato, Louis Hawkins, and Christie Hawkins Amato. 2004. Firm size, strategic advantage, and profit rates in US retailing. Journal of Retailing and Consumer Services 11: 181-93. [CrossRef]

Arafat, Hassan, and Samer Skaik. 2016. How can contractors warrant timely payments in the UAE construction industry. Paper presented at the Construction, Building and Real Estate Research Conference of the Royal Institution of Chartered Surveyors, Toronto, ON, Canada, September 20-22.

Armstrong, Michael. 2006. A Handbook of Human Resource Management Practice, 10th ed. London: Kogan Page Publishing.

Ashworth, Alan. 2006. Contractual Procedures in the Construction Industry, 5th ed. Harlow: Pearson/Prentice Hall. 
Australian Bureau of Statistic. 2014. Counts of Australian Business. June. Available online: https://www.worldcat.org/title/ contractual-procedures-in-the-construction-industry/oclc/1255738858? referer=di\&ht=edition (accessed on 20 February 2020).

Ballantine, John William, Frederick William Cleveland, and Charlie Timothy Koeller. 1993. Profitability, uncertainty, and firm size. Small Business Economics 5: 87-100. [CrossRef]

Bayramova, Aya, David John Edwards, and Chris Roberts. 2021. The role of blockchain technology in augmenting supply chain resilience to cybercrime. Buildings 11: 283. [CrossRef]

Beatham, Simon, Chimay Anumba, Thanh Thorpe, and Ian Hedges. 2004. KPIs: A critical appraisal of their use in construction, Benchmarking. An International Journal 11: 93-117. [CrossRef]

Ben-Caleb, Egbide. 2008. Working capital management and profitability of listed companies in Nigeria. Nigeria Research Journal of Accountancy 1: 44-57.

Berry, Al, Magali von Blottnitz, Rashad Cassim, Anna Kesper, Bala Rajaratnam, and Dirk Ernst van Seventer. 2002. The Economics of SMMES in South Africa. In 2002 TIPS Forum. Johannesburg: Available online: http://www.tips.org.za/files/506.pdf (accessed on 10 December 2020).

Bhavet, Bhavet. 2011. Management of liquidity-A case study of Tisco Ltd. International Journal of Research in IT and Management 149 IJRIM 1: 13-21.

Burton, Ed, David John Edwards, Chris Roberts, Nicholas Chileshe, and Joseph H. K. Lai. 2021. Delineating the implications of dispersing teams and teleworking in an Agile UK construction sector. Sustainability 13: 9981. [CrossRef]

Campbell, John Peter. 1977. On the nature of organizational effectiveness. In New Perspectives on Organizational Effectiveness. San Francisco: Jossey-Bass, pp. 13-55.

Chen, Hong Long. 2009. Model for predicting financial performance of development and construction corporations. Journal of Construction Engineering and Management 135: 1190-200. [CrossRef]

Chiu, Ching-Yi, and Mei-Wei Wang. 2011. An integrated DEA based model to measuring financial performance of construction companies. WSEAS Transactions on Business Economics 1: 1-15.

CIDB. 2012. The Construction Industry as a Vehicle for Contractor Development and Transformation. Pretoria: Construction Industry Development Board.

CIOB. 2004. Construction Act Consultation: “Improving Payment Practices". October 14. Available online: http://www.ciob.org.uk/ ciob/siteRoot/News_Room/Construction_industry_News / Article.aspx?id=724 (accessed on 15 November 2017).

Coad, Alex, and Werner Hölzl. 2010. Firm growth: Empirical analysis. In Papers on Economics and Evolution. 1002. Jena: Max Planck Institute of Economics.

Dahlquist, Magnus, and Goran Robertsson. 2001. Direct foreign ownership, institutional investors, and firm characteristics. Journal of Financial Economics 59: 413-40. [CrossRef]

DTI. 1995. White Paper on National Strategy for the Development and Promotions of Small Business in South Africa Government. Pretoria: Department of Trade and Industry.

Edwards, David John, Iain Rillie, Nicholas Chileshe, Joesph Lai, M. Reza Hosseini, and Wellington Didibhuku Thwala. 2020. A field survey of hand-arm vibration exposure in the UK utilities sector. Engineering, Construction and Architectural Management. [CrossRef]

Edwards, David John, Iain Rillie, Jahangir Akhtar, Nicholas Chileshe, Joseph Lai, and Chris Roberts. 2021. Systematic analysis of driverless technologies. Journal of Engineering Design and Technology. [CrossRef]

Egbide, Ben-Caleb, Olubukunola Uwuigbe, and Uwalomwa Uwuigbe. 2013. Liquidity management and profitability of manufacturing companies in Nigeria. IOSR Journal of Business and Management (IOSR-JBM) 9: 13-21.

Ekpenyong, David B., and Michael O. Nyong. 1992. Small and Medium Scale Enterprises in Nigeria: Their Characteristics, Problems and Sources of Finance. Nairobi: African Economic Research Consortium, paper 16. Available online: www.africaportal.org (accessed on 10 December 2020).

El-Kholy, Amr Metwally. 2014. A multi-objective fuzzy linear programming model for cash flow management. International Journal of Engineering Research and Applications 4: 152-63.

Ellis, James, David John Edwards, Wellington Didibhuku Thwala, Obuks Ejohwomu, Ernest Effah Ameyaw, and Mark Shelbourn. 2021. A Case Study of a Negotiated Tender within a Small-to-Medium Construction Contractor: Modelling Project Cost Variance. Buildings 11: 260. [CrossRef]

Enyi, Patrick Enyi. 2006. Applying relative solvency to working capital management: The break-even approach. In Towards Better Working Capital Management, 2006th ed. Punjagutta: The Icfai University Press.

Etale, Lyndon Miekoromo, Paymaster Frank Bingilar, and Meshack Ifureze. 2016. Market share and profitability relationship: A study of the banking sector in Nigeria. International Journal of Business, Economics and Management 3: 103-12. [CrossRef]

European Commission. 2015. Enterprises and Industry: SME Definition, Archived from the Original on February 8. Available online: http:/ / europa.eu.int/comm/enterprise/enterprisepolicy/smedefinition/index.htm (accessed on 27 April 2020).

Farris, Paul, Neil Bendle, Philip Pfeifer, and David Reibstein. 2010. Marketing Metrics: The Definitive Guide to Measuring Marketing Performance. Harlow: Pearson Education.

Gathenya, Jane Wanjiku. 2012. Entrepreneurial Strategic Planning Practices and Firm Performance among Women Led Small and Medium Enterprises in Kenya. Unpublished Ph.D. thesis, Jomo Kenyatta University of Agriculture and Technology, Nairobi, Kenya. 
Gill, Amarjit, and Neil Mathur. 2011. Factors that influence financial leverage of Canadian firms. Journal of Applied Finance and Banking 1: 19-37.

Graham, John Roderick, and Campbell Russell Harvey. 2001. The theory and practice of corporate finance: Evidence from the field. Journal of Financial Economics 60: 187-243. [CrossRef]

Gschwandtner, Adelina. 2005. Profit persistence in the 'very' long run: Evidence from survivors and exiters. Applied Economics 37: 793-806. [CrossRef]

Gunhan, Suat, and David Arditi. 2005. Factors affecting international construction. Journal of Construction Engineering and Management 131: 273-82. [CrossRef]

Habib, Ashfaq, and Xiaoxia Huang. 2019. CRS investment and cash flow sensitivity under the managerial optimism. Journal of Statistics and Management Systems 22: 11-30. [CrossRef]

Halim, Mohammed, Muhammed Jusoh, Abdullah Osman, and Malus Amlus. 2014. Determining the financial performance factors among Bumiputera entrepreneurs in Malaysian construction industry. Australian Journal of Basic and Applied Sciences 8: 18-24.

Haupt, Theodore Conrad, and Karanagran Padayachee. 2016. Financial Management capacity and business failure of contractors Paper presented at the 10th Building ASOCSA Environment Conference, Porth Elizabeth, South Africa, July 31-August 2; pp. 213-26.

Hooley, Graham I, and James Edward Lynch. 1985. Marketing lessons from the UK's high-flying companies. Journal of Marketing Management 1: 65-74. [CrossRef]

Ibrahim, Abdul Razak Bin, Mathew Roy, Zafar Ahmed, and Ghaffar Imtiaz. 2010. An investigation of the status of the Malaysian construction industry. Benchmarking: An International Journal 17: 294-308. [CrossRef]

Ilori, Jacob Olusegun, and Emmanuel Dele Omopariola. 2018. Analysis of Time Performance of Indigenous Contractors In. Kwara State, Nigeria. The International Journal of Engineering and Science (IJES) 7: 79-86.

Jaring, Jaring. 2009. Factors affecting international construction; challenges and opportunity of Singaporean based company in going abroad. With Great Power Comes Great Responsibilities. Available online: https:/ /indratmojpkuya02.wordpress.com/2009/09/09 / factors-affecting-international-construction-challenges-opportunity-of-singaporean-based-company-in-going-abroad/ (accessed on 29 March 2020).

Jewell, Carol, Roger Flanagan, and Keith Cattell. 2005. The Effects of the Informal Sector on Construction. Paper presented at the ASCE Construction Research Congress, San Diego, CA, USA, April 5-7.

Jónsson, Bjarni. 2007. Does the size matter? The relationship between size and profitability of Icelandic firms. Bifröst Journal of Social Science 1: 43-55.

Khantimirov, Denis. 2017. Market Share as a Measure of Performance: Conceptual Issues and Financial Accountability for Marketing Activities within a Firm. Journal of Research in Marketing 7: 587-92.

Lai, Hui Yin, Abdul Rashid Aziz, and Toong Khuan Chan. 2014. Effect of the global financial crisis on the financial performance of public listed construction companies in Malaysia. Journal of Financial Management of Property and Construction. [CrossRef]

Lam, Terence, and Keith Gale. 2014. Highway maintenance: Impact of framework agreements upon project financial performance. Construction Management and Economics 32: 460-72. [CrossRef]

Larry, Lang Eli Ofek, and RenéM. Stulz. 1995. Leverage investment and firm growth. Journal of Financial Economics 40: 3-29.

Liu, Yaqiong, Zayed Tarek, and Shujing Li. 2009. Cash flow analysis of construction projects. 2nd International/8th construction Specialty Conference. pp. 1-8. Available online: https://pdfs.semanticscholar.org/72b1/55e3c8543315719e6517c2e549560f7fa55b.pdf (accessed on 2 February 2020).

Loo, Siaw Chuing, Hamzah Abdul-Rahman, and Chen Wang. 2013. Managing external risks for international architectural, engineering, and construction (AEC) firms operating in gulf cooperation council (GCC) states. Project Management Journal 44: 70-88. [CrossRef]

Lowe, John, and Elias Moroke. 2010. Insolvency in the UK construction sector. In 26th Annual ARCOM Conference, 6-8 September 2010, Leeds, UK. Edited by Charles Egbu. Edinburgh: Association of Researchers in Construction Management, pp. 93-100.

Maes, Johans, Luc Sels, and Filip Roodhooft. 2005. Modelling the link between management practices and financial performance. Evidence from small construction companies. Small Business Economics 25: 17-34. [CrossRef]

Mahamid, Ibrahim. 2012. Factors affecting contractors' business failure: Contractors' perspective, engineering. Construction and Architectural Management 19: 269-85. [CrossRef]

Matar, Ali, and Bilal Mohammed Eneizan. 2018. Determinants of financial performance in the industrial firms: Evidence from Jordan. Asian Journal of Agricultural Extension, Economics and Sociology 1: 1-10. [CrossRef] [PubMed]

McGahan, Anita, and Michael Eugene Porter. 1997. How much does industry matter, really? Strategic Management Journal Management Journal 18: 15-30. [CrossRef]

Moel, Jadi. 2014. Factors Affecting Firm Value: Theoretical Study on Public Manufacturing Firms in Indonesia. South East Asia Journal of Contemporary Business, Economics and Law 5: 6-15.

Moghadam, Morteza Dadgostar, and Mehrnoosh Jafari. 2015. The role of financial leverage in the performance of companies listed in stock exchange. Indian Journal of Natural Sciences 5: 7402-11.

Moneva, José, and Eduardo Ortas. 2010. Corporate environmental and financial performance: A multivariate approach. Industrial Management and Data Systems 110: 193-210. [CrossRef]

Moneva, Jose, Juana Rivera-Lirio, and Maria Muñoz-Torres. 2007. The corporate stakeholder commitment and social and financial performance. Industrial Management and Data Systems 107: 84-102. [CrossRef] 
Musah, Alhassan, Erasmus Dodzi Gakpetor, and Portia Pomaa. 2018. Financial management practices, firm growth and profitability of small and medium scale enterprises (SMEs). Information Management and Business Review 10: 25-37. [CrossRef]

Naikuru, Susan Ingasia, Jane Gathenya, and Waweru Kamaku. 2016. Influence of firm characteristics on performance of youth led micro and small enterprises in Kenya. IOSR Journal of Humanities and Social Science 21: 26-33.

Naoum, Shamil. 2003. An overview into the concept of partnering. International Journal of Project Management 21: 71-76. [CrossRef]

National Small Business Amendment Act No. 26 of 2003. 2003. Government Gazette. Cape Town: Government Printer, vol. 461, November 26.

Nesan, Jawahar. 2006. Project finance model for small contractors in USA. Australia Journal of Construction Economics and Building 6: 25-41. [CrossRef]

Neshamba, Francis. 2000. Growth and Transformation among Small Businesses in Kenya. Nottingham: The Nottingham Trend University.

Newman, Chris, David John Edwards, Igor Martek, Joseph Lai, and Wellington Didibhuku Thwala. 2020. Industry 4.0 Deployment in the Construction Industry: A Bibliometric Literature Review and UK-based Case Study, Smart and Sustainable Built Environment. [CrossRef]

Norris, William Edward. 1990. Margin of profit: Teamwork. Journal of Management in Engineering 6: 20-28. [CrossRef]

Obert, Matarirano, and Fatoki Olawale. 2010. Does debt really matter on the profitability of small firms? A perspective on small manufacturing firms in Bulaeayo, Zimbabwe. African Journal of Business Management 4: 1709-16.

Odediran, Sunday Julius, and Abimbola Olukemi Windapo. 2016. Financial performance of multinational construction companies in South Africa. Paper presented at the 9th Cidb Postgraduate Conference, Cape Town, South Africa, February 2-4; pp. 92-101.

Ogunsanya, Oluwabukunmi Ayopo, Wellington Didibhuku Twala, Clinton Aigbavboa, and David John Edwards. 2019. Barriers to sustainable procurement in the Nigerian construction industry: An exploratory factor analysis. International Journal of Construction Management. [CrossRef]

Okpamen, Henry, and Sunday Oseiweh Ogbeide. 2020. Board director reputation capital and financial performance of listed firms in Nigeria. Insights into Regional Development 2: 765-73. [CrossRef]

Omondi-Ochieng, Peter. 2018. USA Triathlon: A 2010-15 case study of financial performance using effectiveness indicators and efficiency. Management 67: 1192-213.

Omopariola, Emmanuel Dele, and Abimbola Olukemi Windapo. 2018. Impact of payment systems on construction project and organization performance. Paper presented at the 42nd AUBEA Conference, Singapore, September 26-28.

Omopariola, Emmanuel Dele, and Abimbola Windapo. 2019. Financial Management Strategies That Influence Project and Organisation Performance. In Proceedings of the 35th Annual ARCOM Conference, 2-4 September 2019, Leeds, UK. Edited by Christopher Gorse and C. J. Neilson. Edinburgh: Association of Researchers in Construction Management, pp. 476-85.

Omopariola, Emmanuel Dele, Abimbola Windapo, David Edwards, and Wellington Thwala. 2019a. Contractors' perceptions of the effects of cash flow on construction projects. Journal of Engineering, Design and Technology 18: 308-25. [CrossRef]

Omopariola, Emmanuel Dele, Jacob Olusegun Ilori, and Abimbola Windapo. 2019b. Challenges facing contractors in the execution of public building projects and their impact on performance. Journal of Construction Project Management and Innovation 9: 105-20.

Omopariola, Emmanuel Dele, John Lowe, and Abimbola Windapo. 2017. Effects of cashflow on project delivery in the Nigerian construction industry. Paper presented at the Procs 11th Annual Built Environment Conference, Association of Schools of Construction of Southern Africa, Durban, South Africa, August 6-8; pp. 452-63.

Oyewobi, Luqman Oyekunle. 2014. Modeling Performance Differential in Large Construction Organization in South Africa. Unpublished. Ph.D. thesis, University of Cape Town, Cape Town, South Africa.

Oyewobi, Luqman Oyekunle, Abimbola Oluwakemi Windapo, and Rotimi Olabode Bamidele James. 2015. An empirical analysis of construction organisations' competitive strategies and performance. Built Environment Project and Asset Management 5: 417-31. [CrossRef]

Panayiotis, G. Artikis. 2018. Liquidity as an asset pricing factor in the UK. Journal of Financial Management 6: 18500081-185000824.

Pandey, Indra. M. 2005. Financial Management, 9th ed. New Delhi: Vikas Publishing House PVT Ltd.

Panigrahi, Ashok. 2014. Relationship of working capital with liquidity, profitability and solvency: A case study of ACC Limited. Asian Journal of Management Research 4: 308-22.

Papadogonas, Theodore A. 2007. The financial performance of large and small firms: Evidence from Greece. International Journal of Financial Services Management 2: 14-20. [CrossRef]

Patel, Jignesh. B. 2014. Impact of leverage on profitability: A study of Sabar dairy. International Multidisciplinary Research Journal 1: 1-6.

Pervan, Maja, and Josipa Visic. 2012. Influence of firm size on its business success. Croatian Operational Research Review (CRORR) 3: 213-23.

Phua, Florence. 2006. Predicting construction firm performance: An empirical assessment of the differential impact between industry and firm-specific factors. Construction Management and Economics 24: 309-20. [CrossRef]

Posillico, John, David John Edwards, Chris Roberts, and Mark Shelbourn. 2021. Curriculum development in the higher education literature: A synthesis focusing on construction management programmes. Industry and Higher Education. [CrossRef]

Rachmawati, Andri, and Dan Hanung Triatmoko. 2007. Analisis Faktor-Faktor yang Mempengaruhi Kualitas Laba dan Nilai Perusahaan, Simposium Nasional Akuntansi X Makassar, July 26-28. Available online: https:/ / datakata.files.wordpress.com/20 15/01/akpm-16.pdf (accessed on 21 February 2020). 
Ramanchandra, Thanuja, and James Olabode Rotimi. 2011. Review of Methods for Mitigating Payment Risks in Construction. In International Research Conference on Sustainability in Built Environment. Colombo: Building Economics and Management Research Unit (BEMRU), Department of Building Economics, University of Moratuwa, pp. 198-207.

Rebello, Efigénio. 2005. Small business, SA's biggest test. Engineering News 25: 16-17.

Shakantu, Winston, and Kahilu Kajimo-Shakantu. 2007. Harnessing the Informal and Formal SMME Construction Sectors to Resolve the South African Construction Skills Shortage. In CIB World Building Congress. Denmark: CIB, pp. 2132-39.

Shakantu, Winston M., Kahilu Kajimo-Shakantu, Eric Finzi, and Winfred Mainga. 2006. Bridging the informal, formal and indigenous construction knowledge systems to resolve the construction skills shortage: An exploratory study. Paper presented at the 4th CIDB Postgraduate Conference, Stellenbosch, South Africa, October 8-10.

Sing, Michael, Ivan Fung, Henry Liu, and David John Edwards. 2021. Dynamic Construction Site Layout Planning: An Application of Branch and Bond Algorithm. International Journal of Building Pathology and Adaptation. [CrossRef]

Sliwoski, Leonard James. 2018. Understanding closely held company cash flow. Journal of Corporate Accounting and Finance 29: 83-90. [CrossRef]

Smith, Jessica, David John Edwards, Igor Martek, Nicholas Chileshe, Susan Hayhow, and Chris J. Roberts. 2021. The antecedents of construction project change: An analysis of design and build procurement application. Journal of Engineering Design and Technology. [CrossRef]

Soetanto, Robby, DavidG Proverbs,, and Gary D. Holt. 2001. Achieving quality construction projects based on harmonious working relationships-Clients' and architects' perceptions of contractor performance. International Journal of Quality and Reliability Management 18: 528-48. [CrossRef]

Soewarno, Noorlailie, and Bambang Tjahjadi. 2020. Eco-oriented culture and financial performance: Roles of innovation strategy and eco-oriented continuous improvement in manufacturing state-owned enterprises, Indonesia. Entrepreneurship and Sustainability Issues 8: 341-59. [CrossRef]

Sun, Hongyi. 2000. Total quality management, ISO 9000 certification and performance improvement. International Journal of Quality and Reliability Management 17: 168-79. [CrossRef]

Tam, Angela. 2002. The Development of the MTR Tseung Kwan O Extension. Hong Kong: MTRC.

Tebaldi, Edinaldo. 2014. The Economic Impact of the Construction Industry on the Economy of Rhode Island in 2013. Available online: http:/ / www.newriverpress.com/newsletters/constructionreport.pdf (accessed on 31 March 2020).

Tucker, George Cyril, Abimbola Windapo, and Keith Cattel. 2015. Exploring the use of financial capacity as a predictor of construction company corporate performance: Evidence from South Africa. Journal of Engineering, Design and Technology 13: 1-18. [CrossRef]

Venkatraman, Natarjan, and Vasudevan Ramanujam. 1986. Measurement of business performance in strategy research: A comparison of approaches. Academy of Management Review 11: 801-14. [CrossRef]

Vijayakumar, An, and Perambular Tamizhselvan. 2010. Corporate size and profitability- An empirical analysis. College Sadhana-Journal for Bloomers of Research 3: 44-53.

Voulgaris, Fotini, Dimitrious Asteriou, and George Agiomirgianakis. 2003. The determinants of small firm growth in the Greek manufacturing sector. Journal of Economic Integration 18: 817-36. [CrossRef]

Wang, Guangping, Wenyu Dou, Weichun Zhu, and Nan Zhou. 2015. The effects of firm capabilities on external collaboration and performance: The moderating role of market turbulence. Journal of Business Research 68: 1928-36. [CrossRef]

Winch, Graham M. 2010. Managing Construction Projects, 2nd ed. Orford: Blackwell Publishing Ltd.

Windapo, Abimbola, Sunday Odediran, Alireza Moghayedi, Abdul Adediran, and David Oliphant. 2017. Determinants of Building Costs in South Africa. Journal of Construction Business and Management 1: 8-13. [CrossRef]

Woo, Chungwon, Moon Gym Kim, Yanghon Chung, and Jae Jeung Rho. 2016. Suppliers' communication capability and external green integration for green and financial performance in Korean construction industry. Journal of Cleaner Production 112: 483-93. [CrossRef] 